\title{
Knowledge Exchange Mechanisms and Innovation Policy in Post-Industrial Regions: Approaches of the Basque Country and the West Midlands
}

\author{
Iwona Maria Borowik
}

Received: 20 October 2012 / Accepted: 6 November 2012 /

Published online: 22 December 2012

(C) The Author(s) 2012. This article is published with open access at Springerlink.com

\begin{abstract}
Many countries and regions struggle with utilization of knowledge assets and they developed over the years research and innovation infrastructure to enhance innovation in the private sector. The objective of this study is to review the innovation policy initiatives promoting innovation and cooperation between the regional knowledge base and private sector based on the experience of post-industrial regions of the Basque Country and the West Midlands characterized by similar economic history and challenges in regaining competitiveness. In addition to the mechanisms promoting innovation and knowledge exchange, the study presents the regions' economic background, innovation performance, and institutional framework of innovation policy. The article ends with conclusions and policy implications for other regions.
\end{abstract}

Keywords Technology transfer · Post-industrial regions · Regional innovation policy

\section{Introduction}

Technology and innovation became a central driver of long-term growth. Enhancing competitiveness through "Smart Growth" is in focus of the EU2020 strategy that emphasizes the need to strengthen research performance, improve the conditions for private $\mathrm{R} \& \mathrm{D}$, and promote innovation and knowledge transfer throughout the European Union (European Commission 2010). Member states and their regions are encouraged to reform their innovation systems to foster cooperation between industry and academia, ensure sufficient supply of science and engineering graduates, adjust national funding procedures to support cross-border cooperation, and prioritize business investments in innovation.

The findings, interpretations and conclusions presented in this article are the author's own and should not be attributed to the World Bank Group.

I. M. Borowik ( $\square)$

Financial and Private Sector Development, World Bank Group, Washington, DC, USA

e-mail: iborowik@worldbank.org 
Particularly old industrial regions have been forced to look for new solutions to regain competitiveness. Industrial regions were at the forefront of early industrialization and of capitalist development in the period from 1840 to the 1920 s. They were main drivers of the capitalist economy based on such industries as iron, steel, shipbuilding, heavy engineering, and railway engineering. However, such regions become increasingly marginal with the shift of the economy into Fordist mass consumption sectors throughout the twentieth century and then towards electronic and information technology sectors. Various types of regional policy, including innovation policy, have been pursued to support diversification and modernization activities of existing firms and the formation of new ones (Cooke 1995; Rehfeld 1999).

The objective of this study is to learn about the types of policy initiatives that are used by the post-industrial regions of the British West Midlands and the Spanish Basque Country to foster cooperation between the regional knowledge base and the private sector.

\section{Theoretical Background}

There is a widespread agreement in academic literature that knowledge, learning, and innovation $^{1}$ are essential in economic development and competitiveness for firms, regions, and nations. Innovation ranks on the top of policy agendas today, both in the fields of industrial and regional policy. The dynamic nature of innovation was stressed in the concept of "creative destruction" interpreted as a process where "the opening up of new markets, foreign or domestic, and the organizational development [...] illustrate the same process of industrial mutation, that incessantly revolutionizes the economic structure from within, incessantly destroying the old one, incessantly creating a new one" (Schumpeter 1942, p. 291-317). The concept "open innovation" (Henry Chesbrough 2003) has been popularized in recent years supported on the view that valuable ideas may originate both inside and outside an enterprise as well as they may enter the market using all available channels, including those internal and external to the firm. In this concept, collaboration and networks are increasingly important for innovation. Networks foster knowledge dissemination (Hagerstrand 1952; Lambooy 2005) as they represent a mechanism for the diffusion of innovations by means of cooperation activities and interactions among variety of actors in non-market, inter-firm, and inter-organizational relationships. This stems from the fact that individual enterprises are rarely able to innovate independently, and do not innovate in a vacuum (e.g., Håkansson 1987; Maillat 1995; Florida 1995; Cooke and Morgan 1998; Oughton and Whittam 1997).

Geographical concentration and proximity facilitate innovation (Oort 2003). Regional clusters are perceived as an important dimension in such context. Following

\footnotetext{
${ }^{1}$ The concept of innovation was introduced by Joseph Schumpeter in 1912, defined as an introduction of a new or new quality good, production process (technology), opening of a new market, new organization of any industry, and new inputs. The European Commission referred to the Schumpeter's definition in its Green Paper on innovation (1995) describing innovation as [the] renewal and enlargement of the range of products and services and the associated markets, the establishment of new methods of production, supply, and distribution, the introduction of changes in management, work organization, and the working conditions and skills of the workforce.'
} 
the definition by Enright (1998, p.337) a regional cluster is seen as a "group of firms in the same industry, or in closely related industries that are in close geographical proximity to each other is meant to include geographically concentrated industries included so-called 'industrial districts'. Clusters contain public institutions including government, academia, support services, and are perceived as rich environments for combining different types of knowledge (practical, experience-based, scientific) and facilitate localized learning processes set in social interactions (Gertler 2004). Geographical aggregation and proximity creates opportunities for regions and Regional Innovation Systems (RIS) (Cooke et al. 1998; DelaMothe and Paquet 1998; Fischer 2001; Doloreux 2002). The concept of RIS builds on Triple Helix innovation model (Etzkowitz and Leydesdorff 2000) where academia, government, and industry collaborate with each other creating links between the three helices to discover or develop new knowledge, technology, products, and service. Nonetheless, many regions struggle with weak innovation systems and insufficient innovation performance. This refers to the post-industiral regions that in many cases are characterized by insufficient level of learning capacities and innovation (Cooke 1995; Todtling and Trippl 2004); tend to focus on traditional industries and technology fields (Kaufmann and Tödtling 2000); or rarely achieve interactive learning (Asheim et al. 2003).

Across countries, regional governments introduce a variety of measures fostering collaboration among the innovation helices with an objective to promote knowledge commercialization and private sector innovation. This study investigates regional efforts in fostering innovation and their results based on the cases of the West Midlands and the Basque Country. The two regions were selected given that (1) they were heavily affected by downturn in traditional industries, (2) were forced to profound economic restructuring, and (3) have achieved a very similar overall medium-high innovation performance that may be interpreted as the regions were able to address the challenges and regain competitiveness.

\section{The West Midlands and the Basque Country's Innovation Policy}

\section{Economic Background}

In 2007, the Basque Country and the West Midlands reached 30,600 and 30,300 Euro GDP per capita, respectively, that is above the EU27 average of 24,900 (Fig. 1). The Basque Country's GDP per capita was $30 \%$ higher than Spanish average, while West Midlands GDP per capita was $10 \%$ lower than the national average. Both regions noted an about $120 \%$ growth in this context since 1995 (see Annex I for details).

The West Midlands and the Basque Country are highly industrialized regions. For many years, manufacturing played a prevailing role in economic development (both regions were among the most important regions in Spanish and British industry). In the West Midlands, where the population is about 5.3 million, manufacturing in 2008 amounted to $15 \%$ of regional gross value added (GVA, equivalent to $9 \%$ of the UK manufacturing GVA). In the Basque Country with population of 2.1 million, industrial sector in 2008 represented $25 \%$ of the region's GDP, equivalent to about $11 \%$ of Spanish manufacturing outcome. 


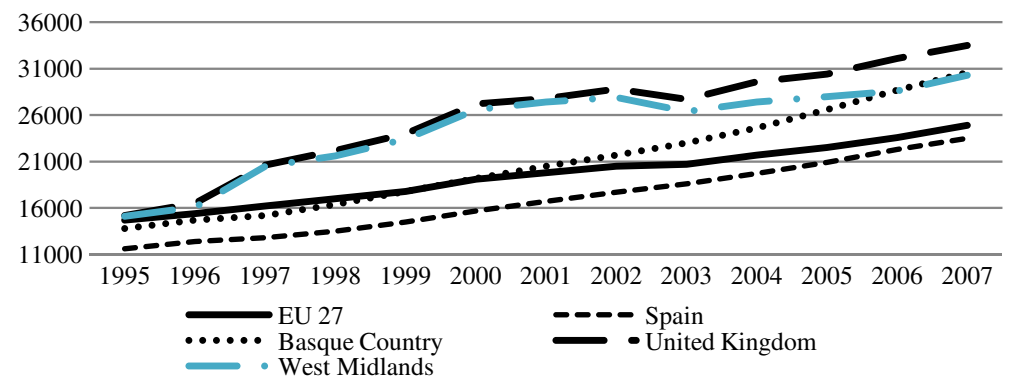

Fig. 1 GDP per capita 1995-2007 (Euro, current market prices). Eurostat

The two regions were heavily affected by downturn in traditional industries (such as pulp and paper, metal, machinery and equipment, rubber and plastic industries, construction, etc.). As a result, the West Midlands and the Basque Country were forced to profound economic restructuring in the 1970s and the 1980s, respectively. As illustrated in Table 1, the West Midlands noted significant decline in manufacturing share as GVA, which was $33 \%$ in 1989, while Basque manufacturing outcome contracted only by about $2 \%$ between 1995 and 2008 .

The awareness of structural problems by leading entrepreneurial actors, public officers, and local stakeholders has set up the ground for a strategic policy review in terms of R\&D and innovation which aimed to meet the key solvable challenges and diversify their economies, upgrade existing sectors, and develop new high-tech ones.

High and medium-high technology manufacturing reveals whether a region invests in technologies of the future or in traditional sectors (medium-low- and lowtechnology manufacturing sector). In the West Midlands and the Basque Country, share of medium-high and high-technology manufacturing in 2007 accounted for 45 and $43 \%$, respectively (Fig. 2). Over the years 1995 and 2007, the West Midlands noted slight increase in medium-high and high-technology manufacturing of $1 \%$ while the Basque Country experienced $11 \%$ increase.

Also, an increase of knowledge-intensive services was observed in both regions (Fig. 3). In 2008, the share of knowledge-intensive services in total services accounted for $54 \%$ in the West Midlands and $47 \%$ in the Basque Country.

Table 1 Industries share (GVA for the West Midlands and GDP for the Basque Country)

\begin{tabular}{llllll}
\hline Sector & \multicolumn{2}{l}{ WM } & & \multicolumn{2}{l}{ BC } \\
\cline { 2 - 4 } \cline { 5 - 6 } & 1989 & 1995 & 2008 & 1995 & 2008 \\
\hline Agriculture & 2 & 2 & 1 & 2 & 1 \\
Manufacturing & 33 & 30 & 15 & 27 & 25 \\
Construction & 7 & 5 & 7 & 6 & 10 \\
Services & 57 & 62 & 75 & 4 & 3 \\
Energy & 3 & 3 & 2 & 41 \\
\hline
\end{tabular}

Author's calculations based on ONS and INE, earlier data for BC not available 
Fig. 2 High and medium-hightechnology manufacturing (as percentage of total manufacturing). OECD

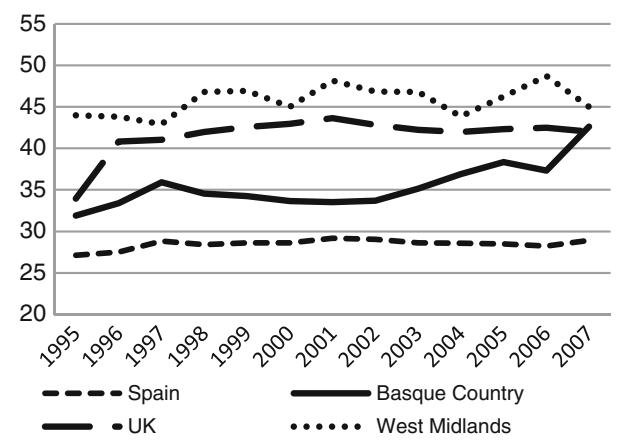

The regions have undergone major economic restructuring over the past two decades, with the relative share of employment and wealth generation transferring to the service sectors, which in 2005 amounted to $79 \%$ in the West Midlands and $63 \%$ in the Basque Country (Table 2). Both regions noted an increase of knowledgeintensive services as percentage of total employment. In 2008, it accounted for $31 \%$ in the Basque Country and $40 \%$ in the West Midlands (Fig. 4).

Regarding employment in high- and medium-high-technology manufacturing as percentage of total employment (Fig. 5), a large decrease from $12 \%$ in 1995 to $6 \%$ in 2008 was observed in the West Midlands. This decline is likely related to decrease of manufacturing in regional GVA as presented in Table 1. In turn, Basque employment in high- and medium-high-technology manufacturing over 1995-2008 as a share of employment has been at constant level of 9-10\%.

To summarize, the West Midlands and the Basque Country recorded about $120 \%$ growth in GDP per capita over 1995-2007. In the context of regional GVA or GDP, manufacturing still plays a considerable role in both regions. Level of high-tech manufacturing is similar in both regions. In this category, the Basque Country has experienced large increase between 1995 and 2007. The percent of knowledgeintensive services in total services is higher in the West Midlands. Analyzing sectoral employment, transfer into the service sectors has been observed in both regions as well an increase of knowledge-intensive services. The West Midlands noted considerable decline in employment in high and medium-high manufacturing which most likely is related to overall decline of manufacturing role in the region, whereas the Basque Country's employment in this category maintained at a similar lever over the years.

Fig. 3 Knowledge-intensive services (as percentage of total services). OECD

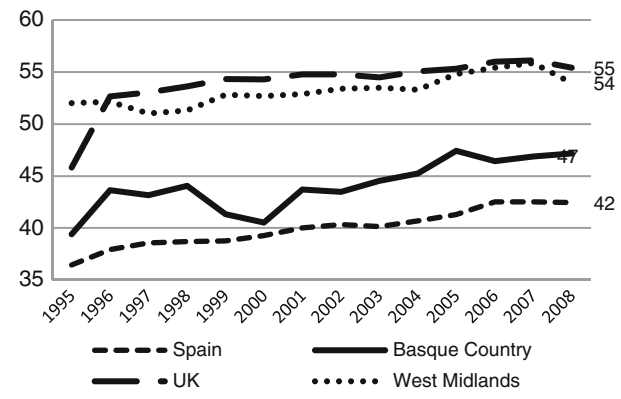


Table 2 Sectoral share of employment

\begin{tabular}{|c|c|c|c|c|c|}
\hline \multirow[t]{2}{*}{ Sector } & \multicolumn{2}{|c|}{ West Midlands } & \multicolumn{3}{|c|}{ Basque Country } \\
\hline & 1998 & 2005 & 1995 & 2005 & 2009(f) \\
\hline Agriculture & 1 & 1 & 3 & 3 & 2 \\
\hline Manufacturing & 24 & 15 & 27 & 25 & 22 \\
\hline Construction & 4 & 5 & 8 & 9 & 8 \\
\hline Services & 70 & 79 & 61 & 63 & 68 \\
\hline Energy & 1 & 1 & 1 & 1 & 1 \\
\hline
\end{tabular}

Author's calculations based on ONS and INE

$f$ forecast

Innovation Policy at the Regional Level and Coordination with the National Policy

Spanish and British regions have a meaningful role in advancing regional innovation. However, essential differences exist between the two regional systems. Spanish autonomous communities are excessively independent on the Spanish government, also with respect to research, development, and innovation policy (RDI). RDI responsibilities are equal across Spanish regions and include regional development policy, technological and scientific parks, research and technology centers, planning and management of EU structural funds, Innovation Relay Centers, and organizations for technology transfer. Additionally, regions offer various subsidies for R\&D projects for firms, universities, cooperative projects, scholarships for PhD students, etc. At the national level, the autonomous communities participate in the advisory bodies of the Interministerial Commission on Science and Technology, and are involved in the formulation of the National R\&D Plan (European Commission 2008). In the case of the Basque Country, the region additionally has fiscal autonomy from Spain; this means that the regional administration is in charge of raising taxes in exchange for a financial contribution to the central government.

In the UK, accountability of the UK RDI policy and its funding belongs to the central government. At the regional level, key role in fostering innovation played the Regional Development Agencies (RADs) by March 2012. Nonetheless, due to a national reform, all RADs were closed, and currently, economic development and regeneration at the regional level is led by central Government departments and newly created Local Enterprise Partnerships (LEPs). Since the new structures and

Fig. 4 Knowledge-intensive services (as percentage of total employment). OECD stat

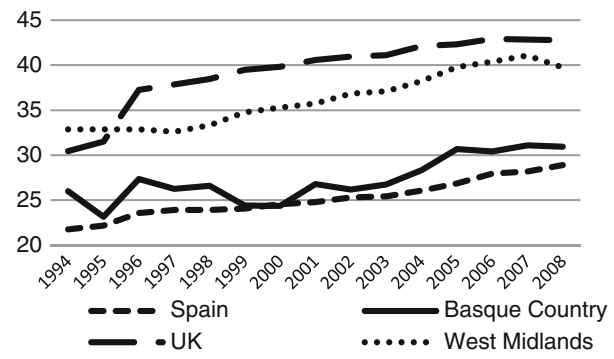


Fig. 5 High and medium-hightechnology manufacturing (as percentage of total employment). OECD stat

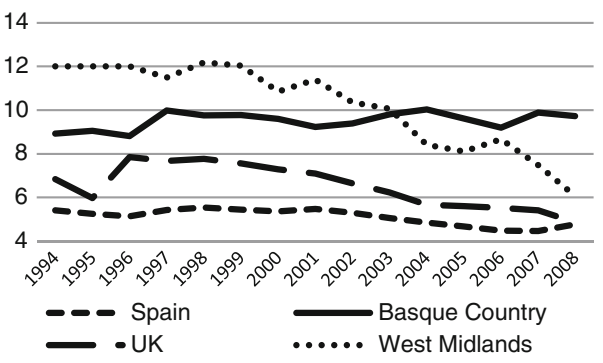

strategies are at the development stage, this study focuses on the recent regional policy conducted by RADs. RDAs were financed by the government and were in charge of strengthening the regional innovation infrastructure, developing strategies, and initiating partnerships to address local and regional innovation challenges. They were main spenders in supporting innovative businesses, managed the cluster policy, and worked with a wide range of partners including universities, colleges, local authorities, UK Research Councils, and the Technology Strategy Board. Moreover, RDAs set up Science and Industry Councils or similar bodies to bring together representatives from both the private sector and universities.

\section{Innovation Policy Objectives in the West Midlands and the Basque Country}

Both regions face the challenge to diversify the manufacturing base into knowledgebased sectors. In that respect, stimulating private sector innovation and investment in R\&D have been pivotal. The regions have launched a variety of measures targeting private sector innovation, including fostering collaboration between enterprises and regional knowledge base that results in knowledge commercialization.

Over the years both regions have developed an extensive regional research and innovation infrastructure in forms of research centers, business incubators, science and technology (S\&T) parks, technology centers, etc. However, the objective now is to effectively utilize the existing infrastructure and knowledge assets and enhance knowledge commercialization that would result in innovation. This is reflected in the regions' innovation policy objectives presented in the Basque Competitiveness Strategy: The Science, Technology and Innovation Plan 2010 (Basque Government 2008) and the West Midlands' Economic Strategy. Table 3 illustrates main innovation objectives of the two regions.

The Basque Country and the West Midlands highlight the importance of enhancing innovation in the private sector focusing on innovation results. This leads to initiatives rooted in the mode 2 concept. Also the role of collaboration networks is emphasized in the form of various mechanisms fostering knowledge exchange between different players in the system-i.e., industry, academia, and public institutions to promote open innovation. This objective emphasizes the role of the triple helix model, where various interactions encourage knowledge exchange and foster the innovation process to provide social and economic benefits. Moreover, both regions are aware of the importance of connectivity to international networks to avoid the lock-in effect, particularly common for economies rooted in traditional 
Table 3 The West Midlands and the Basque Country's innovation policy objectives/priorities

Objective

West Midlands Basque Country

Innovation in the private sector

Promote innovation among enterprises

Improve effectiveness of converting new innovations into turnover

Increase the level of organizational innovation in firms

Advance towards a knowledge-intensive businesses

Diversification towards emerging sectors

Attracting more high value added international businesses to the region

Collaboration

Strengthen mechanisms for knowledge exchange between all players in the system

Broaden collaboration networks with organizations outside the region

Skills and research base

Stimulate the demand for higher level skills and strengthen region's offer to knowledge-intensive businesses

Widening participation in higher education

Create/attract a pool of highly qualified researchers/promote quality research

Cultural change

Promote innovation-related values in the society (social innovation)

WM Knowledge Economy report 2009; Connecting to success West Midlands Economic Strategy Delivery Framework May 2008/2009 (Advantage West Midlands 2007); Plan de Competitividad e Innovación Social 2006-2009, Basque Government; Basque Science, Technology and Innovation Plan 2010

sectors. International networks ensure access to the best and most suitable knowledge for economic actors.

Given that the West Midlands and the Basque Country still largely rely on traditional industries, their objective is to foster knowledge-intensive sectors with strategic meaning for future economic development. This is illustrated by promoting cluster initiatives in high technology sectors. Those are for instance medical technologies or screen, image, and sound in the West Midlands, or microtechnologies, biotechnology, nanoscience, and nanotechnology in the Basque Country.

In relation to skills and research base, the Basque Country puts pressure on attracting to the region's key sectors best international researchers, while the West Midlands struggles with low skills performance in comparison to other UK regions, thus the objective of the West Midlands is to stimulate regional demand for higher level skills and strengthening offer to knowledge-intensive businesses.

Institutional Framework of Innovation Policy in the Basque Country and the West Midlands

The Basque Country has a number of institutions concentrated on fostering innovation (Fig. 6). The Basque Council for Science, Technology and Innovation leads 


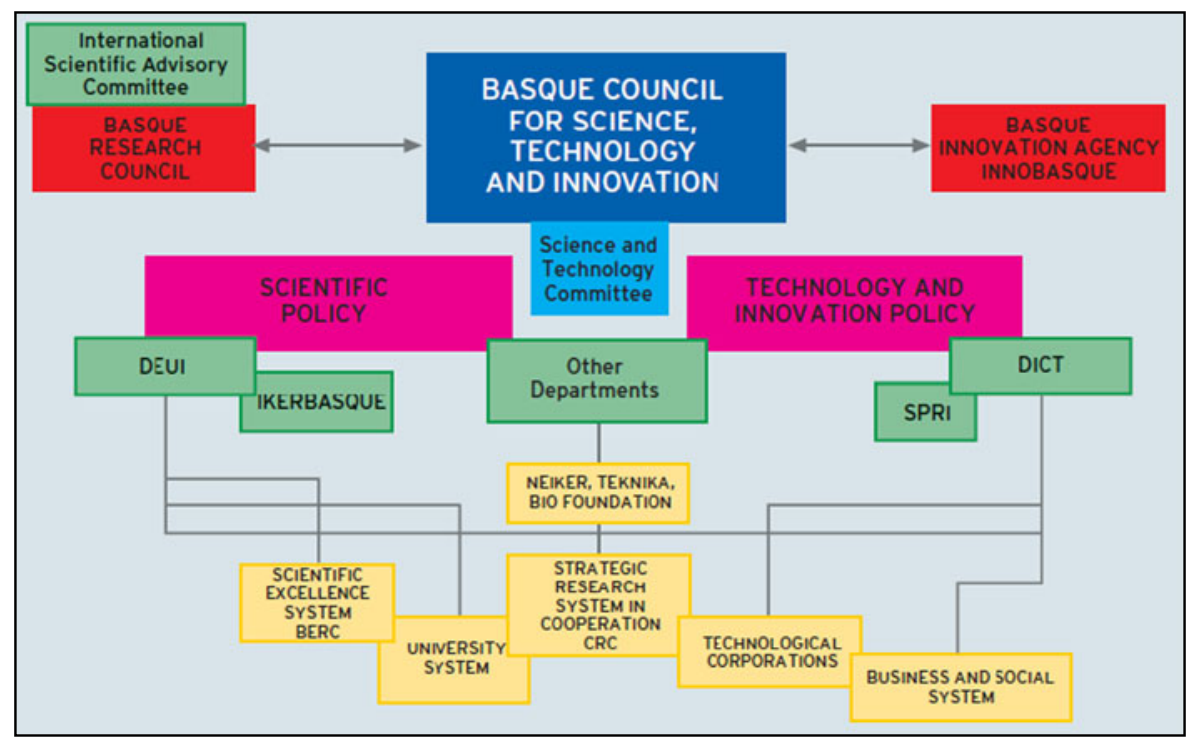

Fig. 6 Management of the Basque Innovation System. Science, Technology, and Innovation Plan, Basque Government, 2010

policies related to science, technology, research, and innovation (Basque Government 2009). The council, supported by the Basque Foundation for Science and Research (IKERBASQUE) and the Basque Innovation Agency (INNOBASQUE), creates pillars maintaining regional research and innovation policies along Basque Science, Technology and Innovation Plan 2010 (Basque Government 2008).

The Basque Research Council monitors, coordinates, and promotes science, development, and innovation in the region. Among others, it promotes the integration of the Basque Research System in the European Research System, advises the Department of Education, Universities and Research and any other organization on research matters; coordinates the measures required for the necessary links between university research and the business system; coordinates networking in research between the Basque universities and the other agents of the Basque Science, Technology and Innovation Network. Other important institutions engaged in science and innovation policy are INNOBASQUE, Ikerbasque, and Network Innovanet. INNOBASQUE is a private, not-for-profit association established to coordinate and promote innovation with the key task to coordinate the Basque innovation system and implement innovation, science, and technology policy, as well as internationalization (it supports SMEs to participate in European Programs), develops mechanisms for monitoring and following up the activities and results of the policy as well as the agents of the System. Ikerbasque (Basque Government 2009), in turn, helps develop scientific research by attracting international researchers and establishing scientific and academic collaborations with national and international universities and research centers as well as the private sector. Finally, Network Innovanet reinforces coordination of regional innovation system to deploy innovation strategy in collaboration with local institutions and organizations. 
In the private sector, innovation main role plays the business development agency of the Basque Country-SPRI. The agency manages $75 \%$ of the budget of the Basque government's Department of Industry, Innovation, Trade, and Tourism and manages programs for innovation infrastructure and private sector innovation.

The Regional Development Agency called Advantage West Midlands (AWM) and the Innovation and Technology Council (ITC) were the critical actors shaping innovation policy until March 2012. AWM was in charge of creating region's economic strategy and the agenda for action plan that provides the basis for the delivery of a wide range of initiatives and programs by AWM and its partners. It was responsible for regional economic development and its key focus area were: skills, enterprise, innovation, manufacturing, access to finance, and business support. AWM was accountable to central government and was responsible for strengthening the regional innovation infrastructure, developing strategies, and bringing together partnerships to address local and regional innovation challenges. ITC was the primary source of advice on innovation to AWM. It was focused on bringing together leaders from the region's science, technology, and industry and developing strong two-way relationships with national policy, particularly through the National Technology Strategy Board and government technology activities. The council also supported universities and research and technology organizations.

\section{Innovation Performance}

In comparison to the world's most innovative economies including Finland or Japan which spend about $3.5 \%$ of GDP on R\&D annually, the Basque Country and the West Midlands spend much less, i.e., 1.9 and 1.3\% of GDP, respectively (Fig. 7). Basque Country's R\&D expenditure exceeds by $0.5 \%$ the Spain's average. The opposite situation is observed in the West Midlands where R\&D spending is $0.6 \%$ lower than the national average.

It has been widely acknowledged that innovation originates in the private sector investments in R\&D. The private sector in the Basque Country spends about $81 \%$ on R\&D that is significantly more than Spanish average of $55 \%$. In the West Midlands, business sector supports $76 \%$ of R\&D, which is more than UK's average of $64 \%$. This compares to Japan, and the US private sector which is responsible for 78 and $72 \%$ of R\&D, respectively (Fig. 8).

Fig. 7 Total R\&D expenditure (GERD) and business R\&D expenditure (BERD), 2008*. Eurostat. *Data for Japan, Basque Country, and West Midlands for 2007

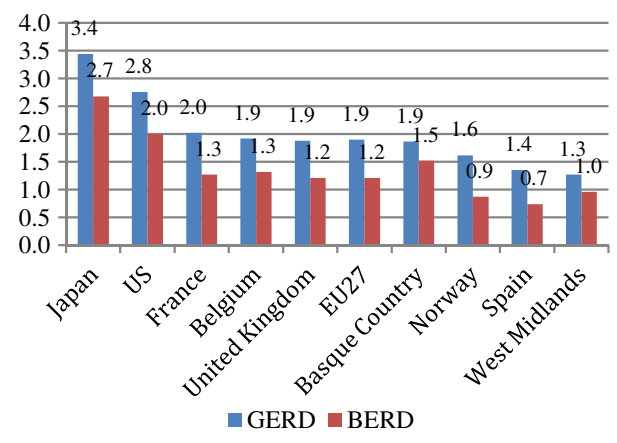


Fig. 8 Share of R\&D financed by the private sector, 2008*. Eurostat. *Data for Japan, Basque Country, and West Midlands for 2007

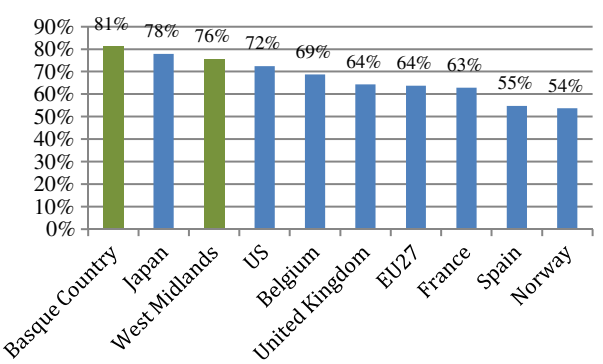

According to the OECD and the European Regional Innovation Scoreboard, RIS (ProInnoEurope 2009a, b), which provide comparative assessment of innovation performance of regions, Basque Country and the West Midlands indicate many similarities. The OECD classifies both regions as medium technology manufacturing and service providers characterized by highly educated labor force, industrial activity, intangibles, and creativity-led sectors and traditional manufacturing activities. With regards to RIS, the study covers about 201 regions for all EU Member States and Norway, analyses regions' absolute strengths and weaknesses using composite indices for three dimensions of innovation performance: innovation enablers (i.e., drivers of innovation that are external to the firm as human resources, finance, and support), firm activities (i.e., innovation efforts that firms undertake as firm investments, linkages and entrepreneurship, and throughputs), and innovation outputs (percentage of SMEs that innovate, sales of new-to-market/firm products, etc.). The scoreboard indicates innovation performance measured by the Regional Innovation Index for all 201 European regions using imputed data. Also, the study searches for similarities in the pattern of strengths and weaknesses across the European regions. As indicated in Table 4, innovation performance of the West Midlands and the Basque Country was classified as medium-high. Both regions have med-high results in indicators of enablers and firms activities, and high outputs in firm innovation activities. The region's relative strengths are in enablers indicators in comparison to the other European regions.

To conclude, both regions suffered a huge decline in their traditional industries and were forced to restructuring. By today, these regions have achieved an overall medium-high innovation performance in comparison to 201 EU regions, particularly gaining high level of outputs (Table 4). Based on that, it may be concluded that the regions were able to address the economic challenges and regain their competitive advantage over the years of transformation.

\section{Regions' Mechanisms Promoting Knowledge Exchange for Innovation}

Recognizing the importance of innovation, the regions have introduced a number of policy schemes to foster innovation in the private sector. Programs include measures enhancing development of linkages between regional science base and industry, in other words, mechanisms supporting transformation of knowledge into innovation. Table 5 briefly highlights major initiatives that exist in the two regions.

The Basque Country's measures that target innovation in business sectors are managed by SPRI. In the West Midlands, private sector innovation schemes are conducted by 


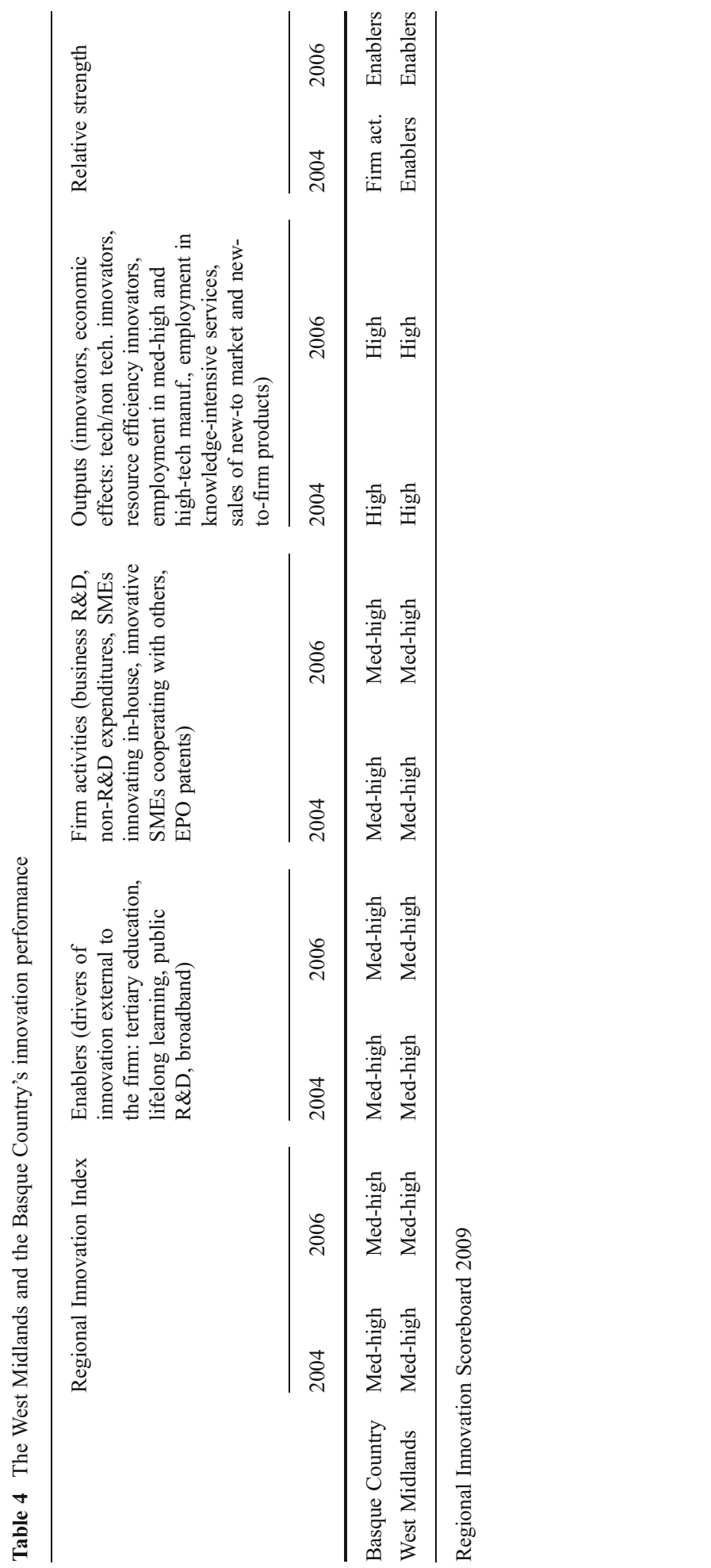


Table 5 Regional innovation and knowledge exchange schemes

The West Midlands

Cluster programs

Business advisory including innovation

Private sector innovation

Recruitment of skilled personnel in enterprises

\section{Strengthening S\&T excellence and reorientation towards market demand}

Developing links between business sector and regional science and technology entities
Business cluster initiatives (13 priority clusters)-Improving competitiveness of regional enterprises in traditional sectors and supporting development of new high-tech industries

Business link services-Business advice and support services

\section{Grant for R\&D (GRD)-Grants} for research and development of technologically innovative products and processes

The innovation networks-Grants for SMEs who are collaborating with at least two others to develop an innovative new product, process, or service

Knowledge transfer partnershipsIncrease of interactions between the knowledge base organizations and companies

Decisions in this area are taken at the national level

Birmingham Science CityDevelopment of hightechnology industries

University-industry voucher scheme-Purchase of academic and research support (fostering collaboration between science and business base) by enterprises

Collaborative Research and Development-Grants for businesses working together and with the knowledge base to develop and exploit new ideas
The Basque Country

Business cluster initiatives (14 priority clusters)-Improving competitiveness of regional enterprises in traditional sectors and supporting development of new high-tech industries

Technology knowledge-intensive business services (TKIBS)Knowledge-intensive support for the business processes

ALDATU-Innovation advisory services for enterprises

GAITEK-Grants for development of new products through $\mathrm{R} \& \mathrm{D}$

INNOTEK-Grants for enterprises for technological development and innovation projects

IKERTU-Recruitment of skilled personnel in enterprises

Cooperative research centers (CIC)-Cooperation platforms to strengthen interdisciplinary basic and applied world-class research in the Basque emerging strategic sectors/ Focus on knowledge transfer into industry

SAIOTEK-Generic and fundamental R\&D

ETORTEK-Human capital development

ETORGAI-Public-private collaboration in strategic industrial research, encouraging SMEs' participation in FP7

NETs-Innovation projects oriented to commercialize knowledge to create new global enterprises

HEDATU-Grants for S\&T diffusion to firms 
Table 5 (continued)

\begin{tabular}{lc}
\hline The West Midlands & The Basque Country \\
\hline $\begin{array}{l}\text { Innovation advantage proof of } \\
\text { concept-Funds for prototyping, } \\
\text { registering intellectual property } \\
\text { rights, market assessments, and } \\
\text { business planning }\end{array}$ & $\begin{array}{c}\text { EMAITEK-Reorientation of } \\
\text { technology centers and their } \\
\text { corporations and technology } \\
\text { alliances towards results and } \\
\text { private sector needs }\end{array}$ \\
\hline
\end{tabular}

Author's elaboration based on West Midlands Knowledge Economy Report (2009); Basque Country Plan de Competitividad e Innovación Social 2006-2009

AWM and are financed by the government. In 2009, to harmonize a variety initiatives targeting private sector among the regions, the government selected and set up a portfolio of 30 publicly funded support schemes that the RDAs may implement in the regions.

Mechanisms Promoting Knowledge Exchange for Innovation in the West Midlands

1. Business Cluster Initiatives. Cluster initiatives have played a key role in addressing the region's deep crisis in the automotive sector at the beginning of the last decade. The West Midlands has launched 13 cluster initiatives since 2003 classified into mature, growing, and embryonic (Table 6). The focus was on upgrading present traditional sectors and developing new high-tech sectors important from the perspective of future economic development. The objective is to 'grow or strengthen regional industries to exploit attractive markets, where the region has existing or potential strengths (Advantage West Midlands 2008, p. 6). These markets also reflect priorities identified by the Innovation and Technology Council and by the National Technology Strategy Board. ${ }^{2}$ During the first cluster programs between 2005 and 2008, the focus was on market exploitation, development of market linkages, technology transfer, development of skills, improvement of supply chain, product innovation, overseas trade missions, strategy planning, and other forms of collaboration (Advantage West Midlands 2009). The cluster initiatives are led by the AWM in collaboration with private sector and regional institutions. Cluster management structure ensures that key local stakeholders from academia and private and public sectors play a vital role in both development and delivery of programs aiming at implementation of projects fostering competitiveness and innovation. Cluster activities are primarily financed by AWM. For instance in period 2005-2008, budget of the Environmental Technologies business cluster amounted to about $€ 7.13$ million. In the West

\footnotetext{
${ }^{2}$ The Technology Strategy Board (TSB) is a business-focused organization dedicated to promoting technology-enabled innovation across the UK. TSB has been established by the Government and operates at arm's length as a business-led executive non-departmental public body. It is sponsored and funded by the Department for Business, Innovation and Skills (BIS).
} 
Table 6 West Midlands and Basque Country cluster initiatives

\begin{tabular}{ll} 
West Midlands cluster initiatives & Basque Country cluster initiatives \\
\hline Mature clusters & Home appliances \\
Transport technologies & Machine tool \\
Building technologies & Automotive \\
Manufacturing & Port of Bilbao \\
Food and drink & Telecommunications \\
Tourism and leisure & Environment \\
High value added consumer products & Knowledge management \\
& Aeronautics \\
Growing clusters & Maritime Industries \\
Business and professional services & Paper, audiovisual \\
ICT & Transport and logistics \\
Environmental Technologies & Biosciencies \\
Embryonic clusters & Energy \\
Medical Technologies & \\
Screen image and sound & \\
\hline
\end{tabular}

Midlands, enterprises do not contribute to the cluster's budget, neither there is formalized cluster membership-in that regard all cluster programs are accessible by any interested and eligible enterprise from the region. Key partners in cluster programs are national public institutions or their regional departments.

Cluster initiatives pursue projects, inter alias, enhancing connection between universities and commercialization of university research results. In the West Midlands, the development of collaboration between research and business sectors may be illustrated by the EnviroINNOVATE project launched by the Environmental Technologies Cluster (Box 1). EnviroINNOVATE concentrated on supporting SMEs in taking up opportunities within the environmental technologies market and creating effective links between academic institutions and SMEs in support of the innovation projects. With program's budget of about $€ 1$ million, 121 businesses created relations with the regional science base. These relations resulted in a number of subsequent innovation projects that levered to $€ 1.7$ million. EnviroINNOVATE not only helped accelerate progress to commercialization, but also provided an interface that understands both business requirements and methods to engage and support academics to work with industry. In result, the region has made a positive link between innovation resources within universities and its SME population in the growing field of Environmental Technologies. 
Box 1. Selected Projects of Cluster Initiatives in the West Midlands (WM) and the Basque Country (BC)

\begin{tabular}{|c|c|c|}
\hline & EnviroINNOVATE, WM & SORMEN, BC \\
\hline Rationale & $\begin{array}{l}\text { Business support through access } \\
\text { to funding and experts from regional } \\
\text { universities to assist a company to } \\
\text { undertake projects of between } \\
5 \text { days and } 6 \text { months }\end{array}$ & $\begin{array}{l}\text { Development of a specific } \\
\text { technology }\end{array}$ \\
\hline Goal & $\begin{array}{l}\text { Development of enduring links } \\
\text { between universities and regional SMEs }\end{array}$ & $\begin{array}{l}\text { Development of metal waste } \\
\text { separation technology }\end{array}$ \\
\hline Financing scheme & $\begin{array}{l}\text { AWM budget } \\
\text { The total cost: } € 1,044,866 \text {, including } \\
€ 202,372 \text { from the ERDF }\end{array}$ & $\begin{array}{l}\text { EU VI Framework Programme } \\
\text { Total cost: } € 1.032 .295, \mathrm{EC} \\
\text { Contribution: } € 686.060\end{array}$ \\
\hline Time & 4 years 2003-2006 & 2 years 2005-2007 \\
\hline Participants & 121 businesses & $\begin{array}{l}4 \text { firms, } 2 \mathrm{R} \& \mathrm{D} \text { centers, ACLIMA } \\
\text { cluster (responsible } \\
\text { for results dissemination) }\end{array}$ \\
\hline Results & $\begin{array}{l}\text { Investment levered: } € 1,71 \text { million } \\
\text { New and protected employment: } 80 \\
\text { New and protected sales: } € 1,483,000\end{array}$ & Technology was developed \\
\hline
\end{tabular}

Source: Projects' documentation

\section{Evaluation of Cluster Initiatives}

Each cluster has its performance indicators (see Annex II for details). Impact of the regional cluster programs is evaluated in line with UK Government guidelines. Over the 7 years from 2002/2003 to 2008/2009, AWM invested about $£ 120$ million in 11 cluster programs, supporting 12,259 businesses. According to an independent evaluation by EKOS Consulting (2008), this compares well with few other regional investments which have had considerably more resources. Based on information from 295 cluster programs and 933 survey responses from program beneficiaries (19\% response rate), among direct results of cluster programs per business are an average: increase in sales of at least $£ 31,000$; increase of profits of $£ 24,530$; reduction of costs of $£ 10,373$ and many others. Overall cluster programs created or safeguarded 6,647 jobs in the West Midlands. One of the most significant benefits reported by beneficiaries are improved relations with the supply chain, and a reduction in factor sourcing costs due to the availability of local suppliers. The survey showed that $21 \%$ of business participants increased their orders to suppliers within the West Midlands and $12 \%$ had increased the number of suppliers within the region. Also, the evaluation estimated deadweight (where benefits would have likely occurred without the cluster program) at the level of $44.8 \%{ }^{3}$ considering an increase in sales; nonetheless, this varies among sectors.

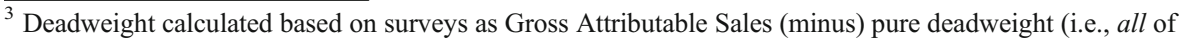
the benefits would take place without the projects) (minus) $50 \%$ deadweight for those stating most of the benefits would have occurred anyway or that they would have occurred but not as quickly; (minus) $33 \%$ deadweight for those stating some of the benefits would have occurred anyway.
} 
Calculating GVA as the additional wages and the additional profits that businesses have generated, cluster programs created total net GVA of $£ 852$ million ( $£ 657$ million in total net GVA to 2008/2009 and $£ 195$ million in future net GVA to 2012/2013). This gives a return on investment of 1:7.1 (i.e., each pound spend by public sector has already or will generate $£ 7.1$ ). It should be emphasized that these results are reflected in high-value sectors which offer good prospects for future growth and are likely to be more sustainable especially when compared to other regional interventions.

2. Birmingham Science City. In 2005, the government defined six Science Cities with strong science-based assets which had particular potential to attract a critical mass of innovative businesses and become drivers of regional growth. Also, Birmingham in the West Midlands was appointed the science city with a long-term strategy of supporting the development of high-technology industry in the region. In collaboration with Birmingham and Warwick universities, over $£ 57$ million has been invested in Birmingham Science City in capital projects related to energy, translational medicine and materials. The first major project is the Hydrogen Energy Project, where AWM's investment of $£ 6.2$ million is part of a 10-year project that is already attracting investment from public and private partners. Progress is being made in several areas comprising development of demonstrators around public procurement as a driver for innovation (particularly low carbon projects) and collaboration with the clusters around demonstrators. Also, Birmingham Science City intends to reinforce capability of regional universities to win EU or other research funding grants as well as connecting to global knowledge networks. As research funding programs require engagement of the private sector, regional business clusters facilitate involvement of their businesses. The Science Cities designation also helped build understanding of the role of science and innovation as a strong promotional tool and developed capacity to innovate within regions through their partnership approach.

3. Business Link Services. ${ }^{4}$ Business Link is a government-funded, regionally managed, and locally delivered free business advice and support service, available online and through local advice service for all size enterprises delivered by AWM. Among its priorities is providing innovation management and advisory services; technology transfer between firms; creation of favorable innovation climate (e.g., awareness campaigns). Over the 12 months of the year 2009-2010 Business Link provided intensive assistance to 13,712 companies; engaged with 74,547 companies through market penetration activities, and improved customer satisfaction from $78 \%$ at the beginning of the year to $93 \%$ at the final quarter (Advantage West Midlands 2010). Evaluation conducted by the University of Warwick, Aston Business School, and Kingston University in 2007 revealed a significant positive effect of Business Link assistance on employment growth, with client employment growth rate of $2.4 \%$. It was acknowledged that the overall impact on the economy of Business Link is positive since for every $£ 1$ spent by the public authorities through the service, $£ 2.26$ of value is generated.

\footnotetext{
${ }^{4}$ Regional Business Link advisory services have terminated in November 2011. Since then the Business Link website became the primary place for businesses to access government-funded business information and support.
} 
4. University-Industry Voucher Scheme. The Innovation Voucher Scheme invites SMEs to apply for a voucher (in the case of the West Midlands it is $£ 3,000$ ) to be used to purchase of academic and research support from any of the 13 regional universities. The program's pilot started in the West Midlands in June 2007 and over 4 years roughly 660 vouchers were provided. The Voucher scheme proved to be highly effective at low cost approach to simulating relationships between universities and SMEs and subsequently was adopted nationally. The evaluation conducted by Ecorys UK emphasized that within 2010 edition of the scheme at the national level: (1) $46 \%$ of SMEs had no previous experience of working with a university, (2) $56 \%$ continue to work with the same or different local university, (3) generated a return on investment of $£ 11.89$ for each $£ 1$ of public sector funding, higher than average of other interventions in the area of R\&D and innovation (£8.30). According to the evaluation of the Scottish scheme of the Innovation Vouchers (BiGGAR Economics 2010), the key advantage of the program is a very quick and simple application process. Among SMEs who participated in the scheme $40 \%$ received support in product improvement, $25 \%$ in R\&D, $15 \%$ in process innovation, and $10 \%$ in brand development. The scheme proved its additionallity since the academics involved in the projects revealed that: project would not have happened without the Innovation Voucher funding (72\%); project met or exceeded their expectations (90\%); knowledge transfer objectives had been achieved (95\%); and would unreservedly recommend the Innovation Vouchers scheme to a colleague (95\%). This program was indicated as best practice by regional policy makers in the West Midlands.

5. Grant for $R \& D(G R D)$. The GRD scheme was introduced in the UK in 2003 and since 2005 was delivered by the regional authorities. GRD helps SMEs to research and develop technologically innovative products and processes through grants up to 20k, 100k, 250k, and 500k. Since its introduction in April 2003, GRD has helped almost 1,700 SMEs nationally to research and develop technologically innovative new products and processes through over $£ 130$ million of grant funding. The program's evaluation (PACEC 2009) found strong evidence of increased technology use and adaptation, a greater commitment to R\&D and innovation by firms, and suggested that some extra external financial support was levered-in by the scheme. Each $£ 1$ million of GRD support (in present value) led to increased annual GVA of between $£ 1.4$ million and $£ 2.1$ million, cumulative GVA of $£ 9.0$ million (with multiplier effects ${ }^{5}$ ) and to between 21 and 32 FTE jobs (the ranges reflect the multiplier effects whether figures give a lower and upper bound for the likely impact of the schemes). National evaluation of the program indicated the majority of respondents, regardless of the types of businesses, acknowledged key effects: $70 \%$ of projects were wholly additional and a further $26 \%$ were partly additional. Firms improved their attitudes/culture towards R\&D and innovation (70\%), the commercial feasibility became clear (84\%), skills were improved (91\%), better able to manage innovation and technical risk (78\%), increased their R\&D expenditure (62\%), and others. Nonetheless, regarding collaboration

\footnotetext{
${ }^{5}$ The Multiplier used is 1.5 based on "English Partnership. The National Regeneration Agency (2004). A Standard Approach to Assessing the Additional Impact of Projects". The value of multiplier is in line with PACEC's National Evaluation of Business Links for DTI, 1998.
} 
with the regional research base, only a little under half of the businesses reported that their participation had had the effect of enabling them to exploit academic/leading edge research. A little under half reported that participation led them to collaborate more with the tertiary sector and with research/technology organizations.

6. Collaborative Research \& Development $(C R \& D)$. A grant for businesses working together and with the knowledge base to develop and exploit new ideas. At the national level, 396 technology enabling and market application projects received $£ 195$ million in grants. According to the evaluation (PACEC 2011) for each $£ 1$ of CR\&D grant, there is an increase in GVA of $£ 6.71$ (or $£ 5.75$ in 2010 prices). The cost per net additional job is $£ 32,000$ (or $£ 36,000$ in 2010 prices). There are likely to be additional impacts as the CR\&D technologies and knowledge is transferred as partners leave their projects or the technology in the public domain feeds into other products, services, and processes. The scheme proved its additionally for $86 \%$ of projects. In relation to collaboration and technology transfer the program has strengthened collaborative activity with businesses $(84 \%)$, provided access to technical advice and R\&D skills (67\%) and academics (73\%). The evaluation suggested that the most effective way in which CR\&D can be used is: (1) through grants of up to $£ 750 \mathrm{k}$ (there was some evidence that grants over $£ 750 \mathrm{k}$ give rise to smaller business performance effects ( $£ 2.34$ of GVA per pound spent) than either grants under $£ 250 \mathrm{k}$ (£10.96) or medium-sized grants, between $£ 250 \mathrm{k}$ and $£ 749 \mathrm{k}(£ 10.01)$ ); (2) Through projects ideally of five to six partners - since these projects gave rise to greater business performance effects ( $£ 8.91$ GVA per pound spent) than either those with only two or three partners (£4.81) or those with six or more partners (£6.57); (3) Through projects with at least one academic partner; (4) in conjunction with other research and innovation programs focused on business support and collaboration.

7. Knowledge Transfer Partnerships (KTP). KTP is a UK-wide program, where three-way partnerships are formed between a business, one or more recent graduates (associates) and a senior academic acting as a supervisor (knowledge base partner). The program is UK-wide and is headed by the Technology Strategy Board and supported by 21 other public sector-funding organizations. The aim of KTPs is to increase interactions between the knowledge base organization and companies through the mediation of the associate who during the period of staying in the company will work on a project developed in collaboration with and co-supervised by the partners for a period from 1 to 3 years. The cost amounts to $£ 16,000$ per year to have a graduate based at the company. Benefits for companies include access to technology, skills, and expertise in the academic science base; benefits for academic partners include: stimulating and fruitful relationship with industry, financial support for release of staff involved in the project Knowledge Transfer Partnerships 2010. The West Midlands is seen as leader in KTP. A program in the UK aims to achieve 210 KTPs by 2012. The main findings published in the 2009/2010 annual report (Technology Strategy Board 2010) show that in $85 \%$ of the cases, the participants have benefited from the scheme and that such benefits will positively influence the future performance of the company. The knowledge base partners have also expressed a positive outlook on the partnership. Ninety-two percent of the knowledge base partners declared that they have benefited through staff development, $85 \%$ reported benefits to research, and $86 \%$ reporting benefits to teaching (Knowledge Transfer Partnerships 2010). 
8. Innovation Advantage Proof of Concept. The measure is directed at universities and businesses to prove that their innovations have significant economic potential. The grant funds prototyping, registering intellectual property rights, market assessments, and business planning. The preferred technology areas are: advanced materials, healthcare technology, energy technology, transportation technology, and digital media. The scheme become very popular and in the year 2008/2009 Advantage West Midlands made GRD offers to 26 businesses amounting to $£ 2.2$ million while in year 2008/2009, 59 grants were committed totaling £1.5 million. The measure has not been evaluated yet thus impact on innovation is unknown.

9. The Innovation Networks. Grants of $£ 10,000$ are available to SMEs who are collaborating with at least two others to develop an innovative new product, process, or service. Projects should contribute to the development and diversification of the regional economy. The measure has not been evaluated yet thus impact on innovation is unknown.

In summary, the region has launched a number of initiatives targeting innovation and almost all of them aim to foster interactions among regional innovation agents. The majority of schemes were evaluated at the national level and show positive results in terms of innovation, investment return, and additionallity. The most successful schemes from the perspective of regional innovation and diversification have been cluster initiatives that largely facilitated development of new high-tech sectors and upgrading the existing ones. Also, a very important role of the universityindustry voucher scheme largely facilitated first contact between the private sector and the science base institutions at a very low cost and in a simple application process if compared with other grant schemes.

\section{Mechanisms Promoting Knowledge Exchange for Innovation in the Basque Country}

Since 2006 the Basque innovation strategy has been oriented towards results. The region has already achieved $R \& D$ capacity, global knowledge as well as excellence in some traditional fields and now aims to develop new innovative sectors. The challenge is to become one of the most innovative regions in Europe and to spread innovation culture among the Basque society (TECNALIA 2009). The region aims to facilitate the adaptation of the research to be carried out in accordance with the demands of Basque clusters and sectors.

1. Cluster Associations. The Basque Country launched cluster policy in the early 1990s which was related to the new Competitiveness Program introduced in 1990 that laid the foundation of the new Basque industrial policy. Since 1992, the Basque Country has created 14 cluster associations (Table 6), with a mission to "Improve the competitiveness of Basque companies through cooperation, focusing on the competitive strategic challenges that cannot be addressed by individual actions carried out by the companies" (Basque Government 2007, p.4). ${ }^{6}$ Clusters, apart from Basque private sector representatives comprise regional technology centers, public institutions, and universities. These entities collaborate in order to

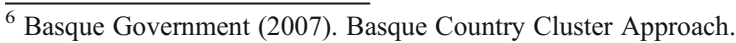


improve business competitiveness, promote innovation, and sustainable development, enhance links between regional administration, private sector, and technology/research centers. Innovation is a top priority for cluster associations. Associations motivate members to cooperate and develop joint projects, then project applications are submitted to regional, national, European funding programs on research or technology development. Projects concentrate on development and delivery of technology or research study where few entities are involved. For instance, projects of the environmental technologies cluster ACLIMA are related to development of new technology, where costs amount to about 1-2 million euro per project (Box 1). They are financed from various programs including EU framework programs, Basque Government programs, provincial councils' funding schemes which cover a substantial part of the project's costs, depending on program type. Each entity has a specific role, e.g., technology creation, development, implementation, project coordination, promotion, and results dissemination (Carayannis and Borowik 2011). Cluster associations are exclusive business associations, managed entirely by the private sector where a company has to become its formal member and pay an annual quota in order to take advantage of cluster services. About $50 \%$ of cluster budget comes from membership fees and the rest is funded the Basque government that signs an annual agreement with the cluster on the amount not higher than $€ 240$ 000 to be spent on daily interactions between civil servants and head of the Cluster Association. Moreover, clusters have primarily regional and international partners. This stems from the fact that the Basque Country is independent from Spain in shaping its own economic policies and to a large extent is independent from the national institutions.

\section{Evaluation of Cluster Programs}

The Basque cluster policy focused on developing cooperation culture among regional enterprises it succeeded in generating cooperation opportunities among private agents and among private and public agents in strategic areas. This has resulted in better knowledge and adoption of public policies by the industry, firms, and other stakeholders. Each cluster sets up annual objectives in the areas of establishing new collaborations, involvement in activities related to sustainability, initiating innovation projects, participation in cluster activities (see Annex II Clusters' Performance Indicators). That said, the majority of cluster results are intangible and difficult to measure, e.g., regarding the trust existing among agents; the public-private collaboration as the main axis of progress; cooperation between competitors. The most important indicator of cluster activities is the number and quality of the projects launched in cooperation in strategic areas of innovation, internationalization, and quality. Up-to-date evaluations based on cluster surveys indicate adaptation of regional policies to the real needs of firms and the improvement in the level of knowledge that firms had about public policies. However, evaluation of program's global impact on competitiveness is missing. Therefore, methodologies should be developed to respond to the evaluation needs of these policies, whether the cluster initiatives had any impact on firm level productivity, employment, and output growth beyond what may have happened in the absence of the interventions, etc. 
2. Technology Knowledge-Intensive Business Services (TKIBS). TKIBS are agents that aim to transfer knowledge into private sector. They target to reinforce the local business base, facilitate modernization, and the adaptation of the production systems of Basque companies to the new global conditions. Role of TKIBS is played by private companies, agents of the Basque Science, Technology and Innovation Network, particularly the technological centers with their development and technological diffusion activities providing knowledge-intensive support for the business processes of other organizations.

3. Cooperative Research Centers (CICs). Cooperation platforms have been designed to create an effective framework of collaboration that strengthens interdisciplinary basic and applied world-class research in order to provide technology transfer and promote competitiveness of the Basque Industry in strategic areas. CICs are instruments to link science and the market. They bring together universities, research institutes, technology centers, companies, and Basque society to develop capacities at emerging sectors of special interest in the Basque Country (as microtechnologies, biotechnology, nanoscience and nanotechnology, energy). CICs focus on knowledge transfer into industry through such instruments as spin-offs, patents, licenses, etc. as well as at projects of global/international significance. CICs have been set up to attract researchers from the international scientific community and create true poles of knowledge with a real international projection. Each research projects builds up a temporary alliance between various actors, such as technological centers, universities, or companies. Currently, seven CICs are in operation, and with a budget of €28 million for 2008-2010 are oriented towards sectoral diversification.

In 2011, the Basque Country allocated about $€ 170$ million on the presented innovation programs (Table 7) and aid instruments directed at fostering innovation in the private sector. All programs are managed by SPRI - the enterprise development agency of the Basque Government.

4. GAITEK. The scheme offers grants for projects for development of new products through R\&D in different socioeconomic sectors. Beneficiaries of this Basque funding program are the small, medium, and large companies, as well as associations and foundations of companies. Other agents like research centers, universities, and public entities can be subcontracted by the beneficiaries of the Basque funding program but only in the case of the complementary actions. The program incentivizes collaboration projects creating synergies between Basque companies and increasing the funding for SMEs.

5. NETS. The measure promotes R\&D and innovation use or generation of marketable knowledge to create new global technology-based companies. It promotes cooperation between the enterprises and regional innovation agents to develop new products and services. In 2008, NETs with budget of $€ 5.6$ million cofinanced 68 projects where 28 companies were created. $^{7}$

\footnotetext{
${ }^{7}$ Information downloaded on 20 January 2011 from the website of Gobierno Vasco, Departamento de Industria, Innovation, Comercio y Turismo http:/www.industria.ejgv.euskadi.net/r44-hm10007/es/contenidos/ ayuda_subvencion/nets_2005/es_8862/es_nets.html
} 
Table 7 The Basque Country's selected programs supporting innovation/competitiveness in 2010

\begin{tabular}{|c|c|c|c|c|c|c|c|c|}
\hline & & $\begin{array}{l}\text { Buget } \\
2008\end{array}$ & $\%$ & $\begin{array}{l}\text { Application } \\
\text { accepted }\end{array}$ & 2010 & $\%$ & 2011 & 2012 \\
\hline GAITEK & $\begin{array}{l}\text { Development of new } \\
\text { products through R\&D } \\
\text { Beneficiaries: all enterprises }\end{array}$ & 22.1 & 22.56 & $342 / 543$ & 22.2 & 13.03 & 37.3 & 37.9 \\
\hline NET'S & $\begin{array}{l}\text { Creation of innovative } \\
\text { and global companies } \\
\text { Beneficiaries: all } \\
\text { enterprises and science } \\
\text { and technology entities }\end{array}$ & 5.6 & 5.77 & $68 / 76$ & 4.0 & 2.35 & 4.0 & 4.0 \\
\hline ETORGAI & $\begin{array}{l}\text { Strategic areas and } \\
\text { sectoral diversification }\end{array}$ & 2.0 & 2.05 & $12 / 15$ & 22.0 & 12.93 & 32.0 & 42.0 \\
\hline HEDATU & $\begin{array}{l}\text { Grants for S\&T diffusion } \\
\text { to firms } \\
\text { Beneficiaries: firms, } \\
\text { foundations, science, } \\
\text { and technology entities }\end{array}$ & 0.3 & 0.26 & $29 / 39$ & 0.20 & 0.12 & 0.3 & 0.3 \\
\hline SAIOTEK & $\begin{array}{l}\text { Generic and fundamental } \\
\text { R\&D (beneficiaries } \\
\text { RCTVI entities) }\end{array}$ & 7.1 & 7.31 & & 14.0 & 8.23 & 6.0 & 6.3 \\
\hline CICs & $\begin{array}{l}\text { Grants to strengthen } \\
\text { CIC S\&T excellence } \\
\text { (infrastructure and } \\
\text { talent attraction) } \\
\text { Beneficiaries: } 7 \text { CICs }\end{array}$ & $\begin{array}{l}28.0 \text { for } \\
2008- \\
2010\end{array}$ & 9.21 & & 10.0 & 5.88 & NA & NA \\
\hline CLUSTERS & & 2.44 & 2.50 & & 2.6 & 1.55 & 2.44 & 2.44 \\
\hline IKERTU & $\begin{array}{l}\text { Fellowships and grants } \\
\text { to support HRST } \\
\text { development } \\
\text { Beneficiaries: individual } \\
\text { researchers and/or } \\
\text { technology-based SMEs }\end{array}$ & 1.71 & 1.75 & & 1.0 & 0.58 & 0.6 & 0.48 \\
\hline ALDATU & $\begin{array}{l}\text { Grant for provision of } \\
\text { services related to the } \\
\text { development of } \\
\text { technological and } \\
\text { non-technological } \\
\text { innovation activities }\end{array}$ & 6.0 & 6.14 & & 6.0 & 3.53 & NA & 5.8 \\
\hline Total & & 99.7 & 100.00 & & 170.1 & 100.00 & NA & NA \\
\hline
\end{tabular}

OECD (2011) Reviews of Regional Innovation. Basque Country; Basque Country, Department of Industry, Innovation, Trade, and Tourism

6. ETORGAI. The program supports implementation of integrated industrial research projects in strategic sectors promoting public-private collaboration in research and technological development and innovation encouraging the involvement of SMEs and access the Seventh European Framework Program for R\&D (EU FP7). The initiative requires collaboration between companies, research institutes, and universities, is multi-year and has a driving effect on the economy 
of the Basque Country. The scheme currently is a flagship program in the Basque Country. Between 2008 and 2011, it helped 684 companies invest 500 million in R\&D and innovation (within 101 projects), where $€ 132$ million were provided by the Basque Government. Participating enterprises are expected to create 1,500 jobs in R\&D, 416 patents, and 900 new products, and generate 68 start-ups. Every publicly invested euro mobilizes at least 2.5 of private contribution. In 2012, Etorgai received 64 business applications will subsidize 256 companies, who will invest 151 million euros (including public funding) in R\&D. The program selects the best $R \& D$ industrial projects through a selection conducted by external professional evaluators. The program is one of the best examples of public-private partnerships and a key player in the Basque system innovation. Budget for this measure has been rapidly increasing every year from $€ 2$ million in 2008 to $€ 42$ million in 2012. About $13 \%$ of the entire 2010 budget for innovation schemes managed by SPRI was devoted to this program.

7. IKERTU. The scheme encourages companies to hire specialized workers with a clear scientific and technological profile to increase a company's competitiveness and capabilities. The main objective of the measure is to support training and enhancing human capital as a key to promote growth and excellence of research potential in the Basque science and technology system.

8. INNOTEK. The scheme existed till 2009 and supported private sector technological development and innovation projects. With a budget of roughly $€ 22$ million per year co-financed by EU structural funds, the program awarded on average 390 projects annually during 2005-2008. ${ }^{8}$ The measure enhances the relations between private sector and the Basque technological centers since subcontracting to these centers is mandatory. It promoted four high-priority areas.

9. ALDATU. Support is given to innovation advisory services to projects aiming to reframe company's strategy, introduce organization, and market innovations and to develop innovation management system. Eligible costs are only the external consultancy costs. They are purchased at market price with public funding of up to $€ 90,000$ per enterprise per year, not to exceed $€ 200,000$ per enterprise within any 3 -year period.

Among measures aiming at improving regional research excellence and its impact on regional competitiveness, the Basque Country implemented HEDATU, SAIOTEK, ETORTEK, and EMAITEK grant schemes. HEDATU supports knowledge transfer from regional research base; SAIOTEK helps the regional R\&D\&I entities carry out fundamental research activities in order to provide value added to companies; ETORTEK promotes human capital development through R\&D cooperation, mobility of researchers, stimulation of PhDs, and career development; while EMAITEK targets technology centers their corporations and technology alliances to reorient toward results and private sector needs as well as look for new opportunities.

\footnotetext{
$\overline{8}$ Information downloaded on 20 January 2011 from the website of Gobierno Vasco, Departamento de Industria, Innovation, Comercio y Turismo http://www.industria.ejgv.euskadi.net/r44-hm10002/es/?results Source $=$ full Text\&catalog Struct $=$ r0 1 e 00000 fe 4 e6676dda $470 \mathrm{~b} 8$ deed $65 \mathrm{c} 9 \mathrm{bfe} 02 \mathrm{f} 4 \mathrm{c} \& \mathrm{catal} \log \mathrm{Label}=$ r01e00000fe4e66771ba470b85e6897e3cbce045d\&fullText=INNOTEK
} 
In summary, the region pays attention to fostering collaboration between a variety of innovation agents. This trend is ilustrated by all measures launched in the region as well the cluster policy which objective is to boost innovation through collaboration at all levels: among firms; between firms, public institutions, and academia, at the international level through participation in EU FP7. Basque Country programs have not been evaluated as the programs in the UK, therefore, it is difficult to identify the most succesful scheme. Based on the analysis of the programs budget (Table 7) it seems that the most important for regional innovation scheme is ETORGAI with increasing annual budget from $€ 2$ million in 2010 to about $€ 42$ million in 2012, increasing number of applications, and successful mobilization of private sector investment in R\&D.

\section{Conclusions}

Post-industrial regions of the Basque Country and the West Midlands have similar industrial history and although they experienced severe decline in their traditional industries, these regions were able to address the economic challenges and regain their competitive advantage. This is reflected in the results of the European Regional Innovation Scoreboard according to which both regions achieved medium-high and high innovation performance in comparison to other EU regions. Both regions noted an increase of high and medium-high technology manufacturing as a share in total manufacturing. At the same time, transfer into the service sectors and an increase of knowledge-intensive services have been observed in the employment structure. Also, the Basque Country and the West Midlands developed regional innovation strategies and innovation governance structures. Nonetheless, although they possess rich research and innovation infrastructure, the challenge they face is to encourage the enterprises to innovate and invest in R\&D.

Recognizing an urgent need to promote business innovation and further sectoral diversification towards knowledge-intensive industries, the regions set a number of innovation priorities reflected in their innovation strategies, containing promoting research commercialization, collaboration between enterprises and the regional research base, development of new strategic sectors and international innovation networks. Reviewing regions' policy initiatives directed at stimulating innovation it may be concluded that the West Midlands and the Basque Country have been using a wide menu of options and even though different programs have been used, they largely target similar innovation challenges.

The implemented initiatives support open innovation and are rooted in Triple Helix framework with focus on encouraging knowledge exchange through collaboration between various actors comprising academia, private, and public sectors at different levels for innovation. Cluster policies have become a key tool of supporting regional diversification and technological upgrade. Cluster initiatives have enabled the regional governments to effectively engage with key regional industries and address regional economic challenges related to post-industrial history of the regions. Nonetheless, cluster initiatives are very unique considering the objectives, priorities, types of projects, financing schemes, and approaches to foster 
innovation, among others. Among similarities, cluster programs are characterized by strong engagement of the private sector, an importance of public-private partnership, and the objective to enhance competitiveness. Moreover, they are market driven, emphasizing the key role of innovation and internationalization. In spite of these analogies, the Basque Country and the West Midlands' cluster programs differ in many ways, for instance in respect to the cluster management, priorities, types of projects, financing schemes, spatial networks, and used performance indicators (Carayannis and Borowik 2011).

Both regions launched various innovation supply schemes, primarily in a form of matching grants. A number of measures were introduced in order to create links between private sector and regional knowledge base. In this context, the West Midlands uses cluster programs, university-industry Voucher scheme, Knowledge Transfer Partnerships, Collaborative Research \& Development grants, and Innovation Advantage Proof of Concept, while the same objective in the Basque Country is supported through cluster projects, as well as ETORGAI, NETs, and INNOTEK schemes.

Both regions advocate development of new strategic sectors and creating links with global players and networks: both region set up cluster programs in new hightech sectors (e.g., in the West Midlands these are medical technologies or screen image and sound clusters, while in the Basque Country cluster of biosciences). Moreover, the West Midlands promotes new strategic sectors through the Birmingham Science City and Innovation Advantage Proof of Concept while the Basque Country recently established a number of Cooperative Research Centers in strategic new sectors, as well as launched the ETORGAI scheme. The two regions offer advisory services to support competitiveness and innovation of regional enterprises. In that area, the West Midlands offers Business Link services, while the Basque Country provides Technology Knowledge-Intensive Business Services and the ALDATU scheme. Also, both regions encourage enterprises to collaborate with each other, for instance in the Basque Country through the cluster initiatives and GAITEK, while in the West Midlands through the Collaborative Research and Development grants.

Regional Policy Differences Looking at the differences in regional innovation policies, it seems that the Basque Country went a step further from the West Midlands towards emerging areas of innovation policy in (1) promoting organizational and market innovation in the business sector (e.g., the ALDATU program), (2) enhancing social innovation which is one of the objective indicated in the innovation strategy ${ }^{9}$; (3) fostering to a larger extend coordination and collaboration among public-private innovation actors (e.g., through Basque Research Council, INNOBASQUE, and network Innovanet). In addition, the Basque Country is highly depended in building regional research base (e.g., CICs). Differences in regional policy approaches primarily stem from the scope of decision power of the Spanish and the British regions versus that of their respective central governments. In the UK, the ministry is in charge of investments in research infrastructure, project

\footnotetext{
${ }^{9}$ The region already has launched initiatives promoting social innovation. However, these schemes are very recent and the results are unknown.
} 
funding for universities research organizations, education and skills, intellectual property protection, $R \& D$ tax credits, and knowledge transfer activities at the universities, whereas the regions decide on the measures that promote innovation in the private sector and enhance collaboration between the private sector and research institutions. A different approach is evidenced in Spain where the autonomous Basque Country has responsibilities in science, education, and innovation policies. This gives the Basque Country large flexibility to launch measures tailored to its needs and the available budget. Also, the Basque Country due to its financial independence can allocate innovation budget towards measures that bring best results for the regional economy.

Best Practices for Other Regions Many regions across the world are faced with similar challenges that were faced by the West Midlands and the Basque Country in terms of enhancing innovation in the private sector and knowledge exchange among private sector, academia, and public sector. In this regard, the West Midlands and the Basque Country provide lessons learned based on their innovation policy experiences. Most of the UK-wide schemes were evaluated at the national level to assess their effectiveness and additionallity. Evaluations were performed against cluster policies, knowledge transfer partnerships, collaborative research \& development, grant for $\mathrm{R} \& \mathrm{D}$ and university-industry voucher schemes. The university-industry Voucher scheme turned the best practice among launched grant schemes, particularly in regard to the investment return, additionallity, and minimum level of red tape in project management. The scheme addressed the main challenge in academia-industry collaborationa lack of funding, essentially among very young or very small businesses. The vouchers scheme differs from other similar measures in the UK that are much more complex or require a very significant commitment from an enterprise. Collaborative research and development grant has been another successful program, although much more expensive from the national budget's perspective. The scheme proved additionallity effects for $86 \%$ of executed projects. In relation to the Basque Country, impact of the innovation schemes has not been assessed, although all the schemes indicate positive results. Regional policy makers point to the ETORGAI program as the best practice in promotion of public-private collaboration and private sector investment in R\&D based on the program's results. The importance of this measure is reflected through its rapidly increasing annual budget between 2008 and 2012 .

Apart from the grant schemes, cluster policy approach could be applied by other post-industrial regions to incentivize economic diversification. The West Midlands cluster model could be a useful tool for larger regions that have available resources and aim to boost few specific sectors, whereas the Basque policy approach could be implemented in regions with an aim to foster innovation through development of a collaboration culture under high budgetary constraints (Carayannis and Borowik 2011).

Open Access This article is distributed under the terms of the Creative Commons Attribution License which permits any use, distribution, and reproduction in any medium, provided the original author(s) and the source are credited. 


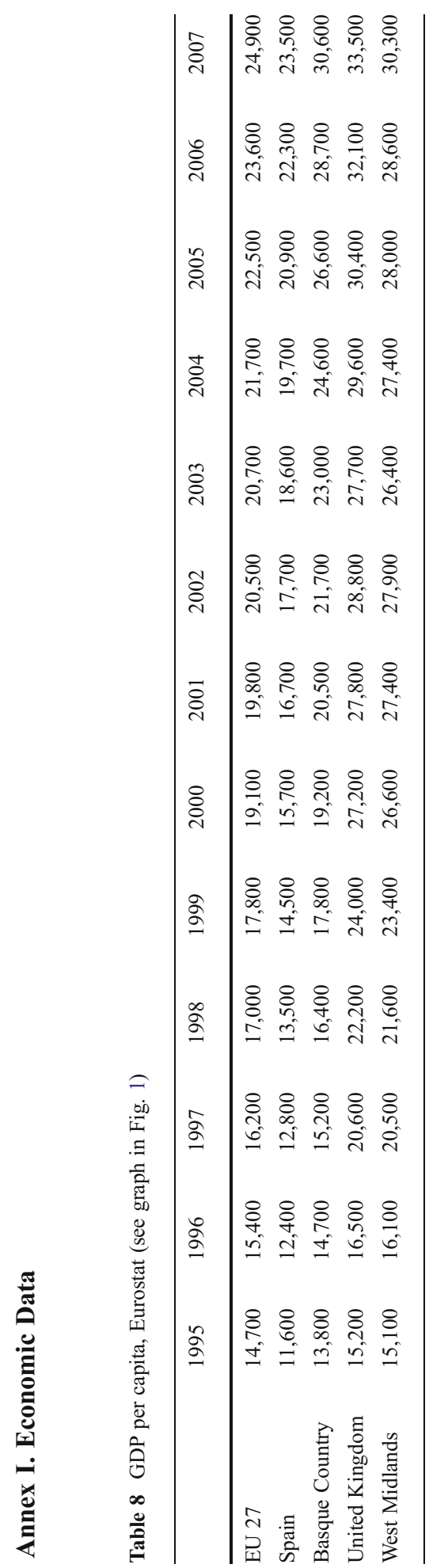


High and medium-high-technology manufacturing (as \% of total manufacturing), OECD

\begin{tabular}{lccc}
\hline & 1995 & 2000 & 2007 \\
\hline Spain & 27 & 29 & 29 \\
Basque Country & 32 & 34 & 43 \\
UK & 34 & 43 & 42 \\
West Midlands & 44 & 45 & 45 \\
\hline
\end{tabular}

Knowledge-intensive services (as \% of total services), OECD

\begin{tabular}{lcccc}
\hline & 1995 & 2000 & 2007 & 2008 \\
\hline Spain & 36 & 39 & 43 & 42 \\
Basque Country & 39 & 41 & 47 & 47 \\
UK & 46 & 54 & 56 & 55 \\
West Midlands & 52 & 53 & 56 & 54 \\
\hline
\end{tabular}

Knowledge-intensive services (as \% of total employment), OECD

\begin{tabular}{lccccc}
\hline & 1995 & 2000 & 2005 & 2007 & 2008 \\
\hline Spain & 22 & 25 & 27 & 28 & 29 \\
Basque Country & 23 & 24 & 31 & 31 & 31 \\
UK & 32 & 40 & 42 & 43 & 43 \\
West Midlands & 33 & 35 & 40 & 41 & 40 \\
\hline
\end{tabular}

High and medium-high-technology manufacturing (as \% of total employment), OECD

\begin{tabular}{llllll}
\hline & 1995 & 2000 & 2005 & 2007 & 2008 \\
\hline Spain & 5 & 5 & 5 & 4 & 5 \\
Basque Country & 9 & 10 & 10 & 10 & 10 \\
UK & 6 & 7 & 6 & 5 & 5 \\
West Midlands & 12 & 11 & 8 & 7 & 6 \\
\hline
\end{tabular}




\section{Annex II. Clusters' Performance Indicators}

\section{The West Midlands}

Performance indicators of the Environmental Technologies Cluster, 2005-2008

\begin{tabular}{|c|c|c|c|c|c|c|c|c|}
\hline & $\begin{array}{l}\text { Obj. 2005/ } \\
2006\end{array}$ & Result & $\begin{array}{l}\text { Obj. 2006/ } \\
2007\end{array}$ & Result & $\begin{array}{l}\text { Obj. 2007/ } \\
2008\end{array}$ & Result & $\begin{array}{l}\text { Obj. } \\
\text { total }\end{array}$ & $\begin{array}{l}\text { Result } \\
\text { total }\end{array}$ \\
\hline \multicolumn{9}{|c|}{ Cluster key performance indicators } \\
\hline $\begin{array}{l}\text { No of companies active } \\
\text { in clustering activity }\end{array}$ & 274 & 271 & 274 & 401 & 274 & 432 & 822 & 1,104 \\
\hline $\begin{array}{l}\text { Of which, companies } \\
\text { assisted to engage in } \\
\text { new collaborations } \\
\text { with the UK } \\
\text { knowledge base }\end{array}$ & 34 & 39 & 34 & 91 & 64 & 73 & 132 & 203 \\
\hline $\begin{array}{l}\text { Number of networking } \\
\text { events }\end{array}$ & 56 & 39 & 56 & 62 & 30 & 59 & 142 & 160 \\
\hline ET business growth & $5 \%$ & $11 \%$ & $5 \%$ & $13 \%$ & $5 \%$ & $16 \%$ & $15 \%$ & $40 \%$ \\
\hline $\begin{array}{l}\text { Regional added value } \\
\text { millions } £\end{array}$ & 3,600 & 64,500 & 3,600 & 81,270 & 3,600 & 45,000 & 10,800 & 190,770 \\
\hline \multicolumn{9}{|c|}{ Project performance indicators } \\
\hline New businesses created & 6 & 8 & 6 & 6 & 7 & 8 & 19 & 22 \\
\hline $\begin{array}{l}\text { Jobs (created and } \\
\text { safeguarded) }\end{array}$ & 240 & 189 & 240 & 171.5 & 240 & 289 & 720 & 649 \\
\hline Businesses assisted & 274 & 395 & 274 & 105 & 263 & 317 & 811 & 817 \\
\hline
\end{tabular}

Source: Cluster documentation

Efficiency indicators of the Environmental Technologies Cluster, 2005-2008

\begin{tabular}{lllll}
\hline & $2005 / 2006$ & $2006 / 2007$ & $2007 / 2008$ & Total \\
\hline Landfill avoidance 21ones pa & 63,011 & 54,000 & 47,110 & 164,121 \\
Cost reductions achieved £'s pa & $13,205,000$ & $8,100,900$ & $4,222,202$ & $25,528,102$ \\
Carbon reduction 21ones pa & 125,042 & 211,027 & 283,355 & 619,424 \\
\hline
\end{tabular}

Source: Cluster documentation

The Basque Country

Economic performance of the ACLIMA cluster

\begin{tabular}{lllllll}
\hline & 1999 & 2001 & 2004 & 2006 & 2007 & $\begin{array}{l}2008 \\
\text { (estimation) }\end{array}$ \\
\hline $\begin{array}{l}\text { Number of members } \\
\text { (enterprises) }\end{array}$ & 55.0 & 63.0 & 74.0 & 77.0 & 82.0 & 87.0 \\
Employment (total) & $23,702.0$ & $27,895.0$ & $31,940.0$ & $36,085.0$ & $51,964.0$ & $59,499.0$ \\
Springer & & & & & &
\end{tabular}


(continued)

\begin{tabular}{|c|c|c|c|c|c|c|}
\hline & 1999 & 2001 & 2004 & 2006 & 2007 & $\begin{array}{l}2008 \\
\text { (estimation) }\end{array}$ \\
\hline $\begin{array}{l}\text { Employment (only } \\
\text { people dedicated } \\
\text { to environmental } \\
\text { industry) }\end{array}$ & $2,454.0$ & $2,888.0$ & $3,797.0$ & $3,872.0$ & $4,276.0$ & $4,722.0$ \\
\hline $\begin{array}{l}\text { Environmental } \\
\text { turnover by employee }\end{array}$ & $205,730.24$ & $240,493.1$ & $250,112.8$ & $359,775.4$ & $278,588.0$ & $267,623.0$ \\
\hline $\begin{array}{l}\text { R\&D investment, } \\
\text { million } €\end{array}$ & $23,679.0$ & 34.8 & 36.2 & 41.8 & 60.4 & 78.0 \\
\hline $\begin{array}{l}\text { Income (environmental } \\
\text { industry only) } \\
\text { million } €\end{array}$ & 504.9 & 694.5 & 761.9 & $1,393.1$ & $1,537.9$ & $1,691.69$ \\
\hline $\begin{array}{l}\% \text { of Basque Country } \\
\text { GDP }\end{array}$ & 1.30 & 1.57 & 1.54 & 2.25 & 2.32 & 2.6 \\
\hline $\begin{array}{l}\text { Income in Basque } \\
\text { Country, million } €\end{array}$ & 208.8 & 287.2 & 303.6 & 448.8 & 641.52 & 795.09 \\
\hline $\begin{array}{l}\text { Income in Spain, } \\
\text { million } €\end{array}$ & 200.0 & 275.1 & 290.8 & 785.4 & 703.5 & 693.07 \\
\hline $\begin{array}{l}\text { International income, } \\
\text { million } €\end{array}$ & 96.1 & 132.2 & 139.7 & 158.9 & 192.84 & 203.8 \\
\hline $\begin{array}{l}\text { Total income, } \\
\text { million } €\end{array}$ & $9,086.7$ & $10,030.7$ & $10,783.0$ & $13,105.9$ & $14,475.74$ & $15,923,314.0$ \\
\hline $\begin{array}{l}\% \text { of Basque } \\
\text { Country GDP }\end{array}$ & 23.4 & 22.7 & 21.8 & 21.2 & 21.8 & \\
\hline
\end{tabular}

Source: Cluster documentation

ACLIMA's indicators

Colaboration

Agreements with public institutions on collaboration

Agreements with private institutions on collaboration

Competitiveness and sustainability

Organization of sectoral workshops to explore new markets

Formation of alliances/consortia within ACLIMA

New members

Involvement in sustainability policy

Members holding quality certificates (e.g., ISO 9001)

Members holding environmental certificates (Ekoskan, ISO 14000)

\section{Obj. $2007 \quad$ Obj. 2008}

$\begin{array}{lllll}\text { Number } & 2 & 3 & 4 & 4 \\ \text { Number } & 2 & 5 & 3 & 3\end{array}$

Number

2

2

$\begin{array}{lllll}\text { Number } & 0 & 7 & 2 & 3\end{array}$

$\begin{array}{lllll}\text { Number } & 3 & 6 & 4 & 4\end{array}$

$\begin{array}{lllll}\% \text { of ACLIMA } & 49 & 46 & 51 & 50\end{array}$

$\begin{array}{lllll}\text { \% of ACLIMA } & 57 & 48 & 60 & 70\end{array}$ 
(continued)

\begin{tabular}{|c|c|c|c|c|c|}
\hline Colaboration & & 2006 & 2007 & Obj. 2007 & Obj. 2008 \\
\hline $\begin{array}{l}\text { Members with EU Eco-Management } \\
\text { and Audit Scheme (EMAS) }\end{array}$ & $\%$ of ACLIMA & 11 & 7 & 13 & 10 \\
\hline $\begin{array}{l}\text { Members with Global Reporting } \\
\text { Initiative (GRI) }\end{array}$ & $\%$ of ACLIMA & 11 & 7 & 13 & 10 \\
\hline $\begin{array}{l}\text { Members with Memoria de Sostenibilidad } \\
\text { Innovation }\end{array}$ & $\%$ of ACLIMA & 12 & 12 & 14 & 10 \\
\hline R\&D project led by ACLIMA members & Number & 1 & 4 & 1 & 3 \\
\hline $\begin{array}{l}\text { R\&D project with participation } \\
\text { of ACLIMA members }\end{array}$ & Number & 3 & 7 & 3 & 4 \\
\hline $\begin{array}{l}\text { Projects revealed in markets with } \\
\text { strategic challenges }(\ldots)\end{array}$ & Number & 1 & 2 & 2 & 2 \\
\hline \multicolumn{6}{|l|}{ Participation } \\
\hline Participation in ACLIMA's conferences & $\begin{array}{l}\text { Average number } \\
\text { of participants }\end{array}$ & 20 & 64 & 30 & 35 \\
\hline Participation in ACLIMA's committees & $\begin{array}{l}\text { Average number } \\
\text { of participants }\end{array}$ & 6 & 12 & 8 & 8 \\
\hline $\begin{array}{l}\text { Number of initiatives/working } \\
\text { groups organized by ACLIMA }\end{array}$ & Number & 0 & 1 & 2 & 2 \\
\hline $\begin{array}{l}\text { Participation in initiatives/working } \\
\text { groups organized by ACLIMA }\end{array}$ & $\begin{array}{l}\text { Average number } \\
\text { of participants }\end{array}$ & 10 & 20 & 15 & 20 \\
\hline \multicolumn{6}{|l|}{ Conferences } \\
\hline Conferences organized by ACLIMA & Number & 2 & 2 & 3 & 3 \\
\hline \multicolumn{6}{|l|}{ Fulfillment of the management plan } \\
\hline Execution of planned activities & $\%$ & 60 & 63 & 80 & 80 \\
\hline
\end{tabular}

Source: Cluster documentation

\section{References}

Advantage West Midlands (2007). West Midlands Economic Strategy. Connecting to Success. the UK: Advantage West Midlands.

Advantage West Midlands (2008). Business Clusters at a Glance. Seizing Market Opportunities. the UK: Advantage West Midlands.

Advantage West Midlands (2009). Cluster Plans 2008-11. Summary. the UK: Advantage West Midlands.

Advantage West Midlands (2010). AWM Annual Report and Accounts 2009-2010. the UK: Advantage West Midlands.

Asheim, B., Isaksen, A., Nauwelaers, C., \& Todtling, F. (Eds.). (2003). Regional innovation policy for small-medium enterprises. Cheltenham: Edward Elgar.

Basque Government (2007). Basque Country Cluster Approach.

Basque Government (2008). Science, Technology and Innovation Plan 2010.

Basque Government (2009). Ikerbasque Basque Foundation for Research. Annual Report.

BiGGAR Economics (2010). Evaluation of the first phase of the Scottish funding council innovation voucher scheme. A final report to Scottish Funding Council.

Carayannis, E. G., \& Borowik, I. (2011). Forms and role of cluster initiatives in fostering innovation in postindustrial regions: a comparative study of environmental technologies clusters in the British West Midlands and the Spanish Basque Country. International Journal of Innovation and Regional Development, 3(3/4). 
Chesbrough, H. (2003). Open innovation: the new imperative for creating and profiting from technology. Boston: Harvard Business School Press.

Cooke, P. (Ed.). (1995). The rise of the Rustbelt. London: UCL Press.

Cooke, P., \& Morgan, K. (1998). The associational economy: firms, regions and innovation. Oxford: Oxford University Press.

Cooke, P., Uranga, M. G., \& Etxebarria, G. (1998). Regional systems of innovation: an evolutionary perspective. Environment and Planning A, 30, 1563-1584.

DelaMothe, J., \& Paquet, G. (1998). Local and regional systems of innovation. Amsterdam: Kluwer Academics Publishers.

Doloreux, D. (2002). What we should know about regional systems of innovation. Technology in Society, 24(3), 243-263.

EKOS Consulting (UK) Ltd. (2008). Evaluation of AWM's Cluster Programme 2002/2003 to 2007/2008. A Final Report for Advantage West Midlands.

Enright, M. (1998). Regional clusters and firm strategy. In A. Chandler, P. Hagström, \& Ö. Sölvell (Eds.), The dynamic firm. The role of technology, strategy, organization and regions. Oxford: Oxford University Press.

Etzkowitz, H., \& Leydesdorff, L. (2000). The dynamics of innovation: from national systems and "Mode 2" to a triple helix of university-industry-government relations. Research Policy, 29, 109-123.

European Commission (2008). INNO-Policy TrendChart-policy trends and appraisal report of Spain.

European Commission (2010). Europe2020. A European strategy for smart, sustainable and inclusive growth.

Fischer, M. M. (2001). Innovation, knowledge creation and systems of innovation. The Annals of Regional Science, 35, 199-216.

Florida, R. (1995). Towards the learning region. Futures, 27, 527-536.

Gertler, M. (2004). Manufacturing culture: the institutional geography of industrial practice. Oxford: Oxford University Press.

Hagerstrand, T. (1952). The propagation of innovation waves. Lund: University of Lund.

Håkansson, H. (1987). Product development in networks. In H. Håkansson (Ed.), Industrial technological development: a network approach (pp. 84-127). London: Croom Helm.

Kaufmann, A., \& Tödtling, F. (2000). Systems of innovation in traditional industrial regions: the case of Styria in a comparative perspective. Regional Studies, 34, 29-40.

Lambooy, J. (2005) Innovation and knowledge: theory and regional policy. European Planning Studies, 13(8).

Maillat, D. (1995). Territorial dynamic, innovative milieus and regional policy. Entrepreneurship and Regional Development, 7, 157-165.

OECD (2011). Reviews of regional innovation. Basque Country.

Oort, F. G. (2003). Urban growth and innovation; spatially bounded externalities in the Netherlands. London: Ashgate.

Oughton, C., \& Whittam, G. (1997). Competition and co-operation in the small firm sector. Scottish Journal of Political Economy, 44, 1-30.

PACEC (2009). Evaluation of grant for research and development \& smart.

PACEC (2011). Technology strategy board. Evaluation of the collaborative research and development programs. Final report. The UK.

ProInnoEurope (2009a). Regional Innovation Scoreboard (RIS).

ProinnoEurope (2009b). Regional Innovation Scoreboard 2009.

Rehfeld, D. (1999). Produktionscluster. Munchen: Rainer Hampp Verlag.

Schumpeter, J. (1942). Capitalism, Socialism, and Democracy (pp. 291-317). Oxford: University Press.

Technology Strategy Board (2010). Knowledge Transfer Partnerships. Annual Report 2009/2010.

TECNALIA (2009). The Role of Research and Technology Organizations in Basque Country Regional Innovation System-The Case of Tecnalia.

Todtling, F., \& Trippl, M. (2004). Like Phoenix from the ashes? The renewal of clusters in old industrial regions. Urban Studies, 41, 1159-1179. 